Published in final edited form as:

Clin Immunol. 2015 August ; 159(2): 143-153. doi:10.1016/j.clim.2015.05.013.

\title{
The Gut Microbiota and Type 1 Diabetes
}

\author{
Elke Gülden ${ }^{1}$, F Susan Wong ${ }^{2}$, and Li Wen ${ }^{1,}{ }^{*}$ \\ ${ }^{1}$ Section of Endocrinology, Yale University School of Medicine, New Haven, Connecticut, USA \\ ${ }^{2}$ Institute of Molecular and Experimental Medicine, Cardiff University School of Medicine, Cardiff, \\ UK
}

\begin{abstract}
Type 1 Diabetes (T1D) is a multifactorial, immune-mediated disease, which is characterized by the progressive destruction of autologous insulin-producing beta cells in the pancreas. The risk of developing T1D is determined by genetic, epigenetic and environmental factors. In the past few decades there has been a continuous rise in the incidence of T1D, which cannot be explained by genetic factors alone. Changes in our lifestyle that include diet, hygiene, and antibiotic usage have already been suggested to be causal factors for this rising T1D incidence. Only recently have microbiota, which are affected by all these factors, been recognized as key environmental factors affecting T1D development.

In this review we will summarize current knowledge on the impact of gut microbiota on T1D development and give an outlook on the potential to design new microbiota-based therapies in the prevention and treatment of T1D.
\end{abstract}

\section{Keywords}

Type 1 Diabetes; gut microbiota; gut permeability; Treg; Th17 cells

\section{Introduction}

Type 1 Diabetes (T1D) is one of the most common metabolic disorders in children and young adults. This autoimmune-mediated disease results in a progressive loss of insulinproducing beta cells in the islets of Langerhans in the pancreas.

Several diabetes-predisposing gene loci have been identified. The strongest association with T1D in humans is with the HLA-DR and -DQ genes, which account for approximately 40-50\% of the disease risk [1]. However, despite intensive research, the triggers for T1D are still mostly unknown, whereas the incidence of T1D has sharply risen worldwide in the past few decades. Currently the overall increase in the incidence of T1D in Europe is about 3-4\%

\footnotetext{
*Corresponding author: Dr. Li Wen, Section of Endocrinology, Yale School of Medicine, TAC-S141, Mail Box 20820, 300 Cedar Street, New Haven, CT 06510. li.wen@ yale.edu.

Publisher's Disclaimer: This is a PDF file of an unedited manuscript that has been accepted for publication. As a service to our customers we are providing this early version of the manuscript. The manuscript will undergo copyediting, typesetting, and review of the resulting proof before it is published in its final citable form. Please note that during the production process errors may be discovered which could affect the content, and all legal disclaimers that apply to the journal pertain.
} 
per year. The fastest increase is observed in children less than 5 years of age [2]. Within this age group the incidence is anticipated to double by 2020 [3, 4]. These dramatic changes in the incidence rate cannot be explained merely by genetic changes. The importance of nongenetic, environmental factors contributing to the disease risk becomes obvious when considering that fewer than $10 \%$ of individuals who are genetically predisposed to T1D de facto develop the disease [5].

Environmental factors that may affect the risk of developing T1D include birth delivery mode [6,7], diet in early life [8-11], and possibly usage of antibiotics [12, 13]. All of these potential environmental risk factors are related to the intestine and its microbiota. The gastrointestinal tract constitutes the largest surface area in the human body and is densely populated by 500-1000 different bacterial species [14]. In recent years, much research effort has been focused on elucidation of the interaction between the host and the gut microbiota in health and disease. The Hygiene Hypothesis, and a more recent refinement, the Old Friends Hypothesis postulates that the increase in the incidence of allergy and autoimmune diseases in Western Countries is associated with reduced or delayed exposure to microbes or parasites in our childhood [15]. The disappearing microbiota hypothesis in contrast focuses more on our ancestral microorganisms rather than cleanliness and postulates the lack of symbiotic microorganisms as being responsible [16]. Numerous studies have documented that coevolution with the microbiota has led to interdependence between the human host and the commensals, which are crucial for maintaining homeostasis. Disturbing the homeostasis, so-called dysbiosis, will have an important impact on immune responses that have been observed in different diseases. Recent studies also suggest that the gut microbiome contributes to the risk of developing T1D in genetically predisposed individuals [Tab. 1].

As various environmental factors that are known to influence the risk of developing T1D also modulate the composition of the gut microbiome [Fig.1], it is reasonable to consider microbiota to be a link between those factors and disease promotion, which will be discussed below.

\section{Gut Microbiota and their Effect on T1D}

Accumulating evidence from human studies emphasizes the crucial role of the composition of the gut microbiota in diabetes development. Patients with T1D exhibit a less diverse and less stable gut microbiome compared to healthy controls $[17,18]$ and changes of the ratio of Firmicutes to Bacteroidetes have been observed in the patients [17-20]. Prediabetic children harbor more Bacteriodetes compared to controls [19]. A decreased abundance of Faecalibacterium prausnitzii (butyrate-producing bacterium) in children who had more than two diabetes-related autoantibodies has also been observed [21]. However, these studies are limited at present and there is considerably more evidence in mouse models that had fuelled these studies in humans as discussed below.

The fact that the incidence of T1D in non-obese diabetic (NOD) mice is influenced by the microbial environment in different animal facilities worldwide [22] had suggested that microbiota play a crucial role in diabetes development. 
Some early studies showed that NOD mice developed exacerbated diabetes under germ-free (GF) conditions, however, the recent reports did not confirm a disease aggravation in NOD mice housed in GF conditions [23, 24]. King, et al. demonstrated that an accidental contamination with Bacillus cereus in one cohort of otherwise GF NOD mice resulted in delayed diabetes onset and decreased incidence [23]. Hence, it seems more likely that the composition of the gut microbiome and the richness of certain bacteria are the key factors modulating diabetes development. Our recent study provided a strong evidence of another important player - innate immunity. Myeloid differentiation primary response 88 (MyD88) is a 'master' adaptive protein down stream of most innate immune molecules [25]. MyD88deficient NOD mice were completely protected from diabetes development when housed in specific pathogen free (SPF) conditions; however, GF MyD88-deficient NOD mice developed full-blown diabetes. Colonization with defined gut bacteria restored diabetes protection in those mice although not $100 \%$ [26]. Our results reveal a novel influential pathway of innate immunity in T1D development through gut microbiota.

Individual strains of the gut bacteria may have different effects on diabetes. Using the Biobreeding (BB) rat model, Valladares and colleagues reported that Lactobacillus johnsonii isolated from diabetes-resistant BB (BB-DR) rats can attenuate diabetes development in diabetes-prone BB (BB-DP) rats whereas Lactobacillus reuteri, also from BB-DR rats, failed to affect diabetes development [27]. Contrary results were also obtained in terms of segmented filamentous bacteria (SFB) and their effect on diabetes development. Kriegel and coworkers reported an association between SFB colonization and diabetes protection in female SPF NOD mice [28], whereas using GF female NOD mice, Yurkovetskiy and coworkers found SFB did not confer protection in monocolonized gnotobiotic NOD females [29]. The authors showed that the protective effect of SFB could only be seen when other gut bacteria were present [29]. One explanation for this disparity is that SFB act in concert with other bacterial species to modulate the disease. Variations in SFB strains could also be responsible. Interestingly, male GF NOD mice were protected from diabetes development even monocolonized with SFB [29]. This suggests a complex association of sex hormones, gut microbiota and beta cell autoimmunity.

\section{Gut Permeability and T1D Induction}

The intestinal epithelial layer constitutes a barrier that separates the luminal antigens from the interior of the body. The adjacent epithelial cells exhibit lateral connections, namely tight junctions, which seal the paracellular space. Tight junctions consist of transmembrane barrier proteins such as occludin and claudins, which form fibrils that interact with the neighboring cell [30]. Intracellular scaffold proteins like ZO-1 - ZO-3 link the transmembrane barrier proteins to actin and microtubules, which play a decisive role in the architecture as well as the physiology of the tight junctions. The design of the intestinal epithelial barrier prevents food antigens, pathogenic as well as commensal bacteria from leaving the gut lumen and inducing a systemic immune response. Disruption of this crucial intestinal barrier is associated with intestinal autoimmune disorders including inflammatory bowel disease [31, 32], celiac disease [33], and irritable bowel syndrome [34]. Impaired integrity of the intestinal barrier, with increased permeability, has also been documented in both animal models and human T1D studies [Tab.2]. 
A study by Bosi and colleagues suggested that the increased gut permeability preceded the clinical onset of T1D [35]. Ultra-structural mucosal alterations and increased intestinal permeability in patients with T1D [36]. These studies support the notion that in genetically predisposed individuals impaired gut permeability may allow luminal antigens to escape the gut and promote islet-directed autoimmune responses. However, all the studies, thus far in humans, have not proven that the increased gut permeability is the cause and not a consequence of T1D onset. It is unlikely that increased gut permeability alone will be sufficient to induce T1D.

Increased intestinal permeability before the onset of diabetes was also seen in rodent models of T1D [37, 38]. In genetically modified NOD models, including MyD88-deficient mice, which lack the ability to signal through many of the innate immune Toll-like receptors (TLRs) and have altered diabetes development, for example, show increased gut permeability [39] but fail to accelerate diabetes development when maintained under SPF conditions [26]. This argument is reinforced by a study performed by Hadjiyanni and colleagues [40]. They showed that enhancement of the gut barrier function in NOD mice by applying a Glucagon-like peptide-2 did not result in delayed or decreased diabetes development [40].

Other rodent studies, however, suggest that increased gut permeability may be the cause rather than a consequence of T1D. Lee and colleagues demonstrated that gut barrier disruption induced by $C$. rodentium infection accelerated insulitis in NOD mice [41]. Likewise, if the mice were infected with a strain unable to disrupt gut integrity, insulitis was not affected. Visser and colleagues demonstrated that the gut permeability in BB-DP rats could be modulated by a hydrolysed casein diet [42]. Administration of this diet resulted in an improvement of the gut integrity and in prevention of T1D. Gut permeability can also be modulated through stimuli other than dietary products, which affect the function of the tight junctions in the epithelial layer [43]. Among these stimuli are inflammatory mediators, peptides produced by gut endocrine cells and microbial agents. Several of these agents induce the up-regulation and secretion of zonulin into the gut lumen by lamina propria cells $[43,44]$ (and our unpublished observation). Secreted zonulin is recognized by its receptor on intestinal epithelial cells. Signaling through the zonulin receptor causes remodeling of the cytoskeleton and down-regulation of ZO-1 and occludin [45]. This disassembly of the tight junctions results in enhanced gut permeability $[43,45]$. The detrimental effect of zonulin on the gut barrier function was confirmed by Watts and coworkers. Using a zonulin antagonist in their study, the authors demonstrated that the improved gut integrity in BB-DP rats was accompanied by protection from developing T1D [46]. In accordance with this finding, a human study showed that zonulin upregulation in T1D patients and their high-risk-relatives was associated with increased gut permeability [47]. However, unlike the rodent study, clinical administration of a zonulin antagonist to patients with celiac disease failed to improve gut permeability [47]. To conclude from the aforementioned studies, gut permeability may be an important player in the development of T1D but, as yet, the findings in human studies have shown association but causation will be more difficult to prove. 


\section{Diet, Gut Microbiota and T1D}

Early childhood ( $\leq 3$ month) introduction to cereals $[10,11]$ and cow's milk [48] were shown to promote beta cell autoimmunity. It is interesting, in light of the gut involvement in T1D development, that different diets influence the incidence of diabetes in NOD mice [49, 50]. This dietary effect has also been shown in animal models where a gluten-free diet prevented diabetes in NOD mice [50]. In connecting these to alterations in the microbiota, a recent animal study revealed an association between low diabetes incidence in NOD mice raised on a gluten-free diet and alterations in the gut microbiota composition [51]. Similarly, in the BB-DP rat, a diet of hydrolyzed casein reduced the incidence of diabetes compared with a cereal-based diet [52]. Other dietary factors, including the acidity of water influences T1D risk in NOD mice through modulation of the microbiome [53].

The other dietary means by which gut bacteria could be altered includes the ingestion of probiotics - 'live microorganisms that, when administered in adequate amounts, confer a health benefit on the host' [54]. There is no data as yet available as to whether this might be a factor of influencing type 1 diabetes development. Many bacteria have been suggested to have probiotic effects through different mechanisms, including effects on barrier function of the gut. A study has documented a beneficial effect of Lactobacillus plantarum on barrier function [55].

A recent study by Patel and coworkers addressed the notion that probiotics could beneficially influence the gut permeability in animal models [39]. Their study documents the observation that the probiotic Lactobacillus rhamnosus $G G$ promotes the maturation of the intestinal barrier by induction of claudin-3 expression. Lactobacillus johnsonii was also shown to induce claudin [27]. Prebiotics which are defined as 'nonviable food components that confer a health benefit on the host associated with modulation of microbiota' [56] are also known to improve the gut barrier function by improving tight junctions [57]. These findings suggest that prebiotics and probiotics could be potential therapeutic tools to improve gut integrity in various intestinal inflammatory and autoimmune diseases including T1D.

\section{Mode of Birth, Early Life Feeding and T1D}

The increased T1D incidence in babies who were delivered by Cesarean section has recently been found to be associated with altered composition of gut microbiota [6, 7]. The birth delivery mode determines which bacterial strains first colonize the newborn baby's gut. Infants who were born by Cesarean section had a gut microbiome that resembled the bacteria from the mother's skin [58] whereas infants who were born by vaginal delivery had gut flora predominantly resembling the bacteria in the mother's birth canal [58]. However, little is known about the effect of mode of birth on the immune system.

The newborn baby's intestine is first exposed to bacteria during the birth; their gut microbiome afterwards is mainly shaped by feeding behaviors, such as breast feeding or bottle feeding. Human breast milk is not sterile and many bacteria including Lactobacillus gasseri, Lactobacillus rhamnosus, Lactobacillus plantarum, Lactobacillus fermentum or Enterococcus faecium which are considered to be probiotic bacteria have been found in 
human breast milk [59]. It is not surprising, therefore, that the breast-fed and bottle-fed infants differ in the composition of their gut microbiomes. The intestine of breast-fed infants is mainly colonized by Bifidobacteria and Lactobacilli [60] whereas bottle-fed infants show markedly decreased numbers of those bacteria but increased numbers of Enterobacteriaceae and Bacteroides [60, 61]. However, not all studies have found a clear distinction in gut bacteria between breast and bottle-fed babies [62] and it is controversial whether breast feeding is protective from T1D development. Some studies showed that the breast feeding reduced the risk and/or prolonged the time to T1D onset $[8,9]$, whereas other studies presented opposite findings [10,11]. The beneficial effect of breast feeding suggested by some studies might be based on the promotion of gut maturation [63] and thus decreased gut permeability. In the mature gut, permeability is shaped by gut microbiota through degradation and fermentation of carbohydrates into short-chain fatty acids (SCFA) [17, 64]. Butyrate has been shown to enhance the intestinal barrier by regulating the assembly of tight junctions [65] and is also crucial for sufficient mucin synthesis [17]. The production of mucin, which is essential for a healthy gut, is counteracted by non-butyrate producers in autoimmune individuals. In line with this concept is a study showing a decreased abundance of Faecalibacterium prausnitzii (butyrate-producing bacterium) in children exhibiting more than two diabetes-related autoantibodies [21].

Some insight into immunological changes in the offspring has been shown in a recent study in NOD mice where fewer regulatory $\mathrm{T}$ cells were found in the mice born by Cesarean section, although in this study, no alteration in diabetes incidence was observed [66].

\section{Antibiotics and T1D}

Antibiotics have been used in modern societies to treat infections caused by pathogens. As a consequence, the intestinal microbiome is affected by antibiotic usage [67]. The use of the antibiotics can have long-term effects [7, 68]. However, to date, there is no direct evidence that antibiotic use in humans affects the development of T1D.

Animal studies demonstrate that antibiotic-induced modulation of the gut microbiome affects autoimmune diseases [12, 69]. A recent study showed that oral antibiotic treatment of pregnant mice could alter the gut microbiota composition in the offspring; but there was no significant change in diabetes development [70]. Other studies, however, demonstrate that the modulation of the gut microbiota composition by antibiotic treatment affects diabetes development in NOD mice and BB-DP rats [12,13]. Long-term vancomycin treatment depleted many major bacteria genera, except for the species Akkermansia muciniphila, which became dominant and inhibited diabetes development in NOD mice [13]. However, it is noteworthy that diabetes development was critically affected by the type of antibiotic used as well as the timing of treatment. Our recent study suggests that targeting Gram-negative bacteria protects NOD mice from diabetes development whereas depleting Gram-positive bacteria accelerated diabetes in NOD mice (Hu et al., unpublished). Our study also indicates that the most effective time of treatment is early in life (Hu et al., unpublished) which is consistent with other studies of early-life microbiota disruption and other metabolic disorders, such as obesity [71]. 


\section{Gut Immune Responses and T1D}

As with many other aspects of interest in gut microbiota and the intestine that may play a role in development of T1D, the hypothesis that the gut microbiota may play a role in autoimmune diabetes development in humans is of considerable interest. However, studies are still at the early stages and mechanistic data is not easy to obtain in humans.

Much of the information has again come from animal models. In addition to affecting the gut integrity, gut microbiota also modulate the immune system. Colonization of the host's intestinal tract by microbiota is crucial for the development of the immune system as shown by the fact that GF mice exhibit underdeveloped intestinal and systemic lymphoid tissues [72]. Furthermore, they also have altered lymphocyte development and function [73-75], among which is the reduced Foxp3 expression in mucosal $\mathrm{T}$ cells and impaired regulatory function of Foxp3 ${ }^{+} \mathrm{T}$ cells (Treg) [24]. Monocolonization of GF mice with the commensal Bacteroides fragilis, however, promotes the differentiation of Treg and the production of the anti-inflammatory cytokine interleukin-10 [76]. The immunomodulatory effect of Bacteroides fragilis is mediated by the bacterial polysaccharide A (PSA) that induces the conversion of $\mathrm{CD}^{+} \mathrm{T}$ cells into $\mathrm{CD} 4^{+} \mathrm{Foxp}^{+}$Treg. Commensal bacteria also influence immune cells via their metabolites. The microbial metabolite butyrate, for example, can induce Treg cells [77, 78]. The immune-modulatory effect of gut microbiota was further evident in the study by Olszak and coworkers. They demonstrated that early life exposure to microbes had persistent effects on natural killer $\mathrm{T}$ cell function. Our own study showed that germ-transfer from diabetes-protected MyD88-deficient NOD mice to wild type mice resulted in an increase in $\mathrm{CD}^{+} \mathrm{CD}^{-103^{+}}$and $\mathrm{CD} 8 \mathrm{a} \beta \mathrm{T}$ cells in the lamina propria [68].

Both $\mathrm{CD}^{+}(\mathrm{Th} 1)$ and $\mathrm{CD} 8^{+} \mathrm{T}$ cells contribute to the islet beta cell destruction in T1D. The role of Th17 T cells is also considered by some to be crucially involved in the pathogenesis of T1D [79, 80]. However, other investigators claim a diabetes-protective role of IL17producing T cells $[28,81]$. GF mice show impaired secretion of IL-17 in their lamina propria $[24,82]$, which is a thin layer in the mucosa beneath the intestinal epithelium. Lau and coworkers have recently reported that T1D protection in BB-DP rats after giving Lactobacillus johnsonii N6.2 was mediated by Th17 cells in mesenteric lymph nodes (MLN) [cf. section 'Gut Permeability and T1D Induction'] [81]. The fact that non-gut-draining lymph nodes lack a Th17 bias suggests that interactions between Lactobacillus johnsonii N6.2 and immune cells in the MLN are responsible for this bias that is most likely to contribute to the diabetes protection. The influence of distinct microbiota on the differentiation of Th17 cells in the small intestine was also shown by Ivanov and colleagues $[82,83]$. They identified the commensal SFB as inducers of Th17 cells [83] and the lack of Th17-inducing commensals resulted in an increase of Treg in the lamina propria, which suggests that the microbiome regulates the balance of Th17 cells and Treg [82]. However, $\mathrm{T}$ cells featuring an IL-17A effector function are a heterogeneous population that has various effector functions. Therefore, further studies are needed to elucidate whether IL17A or another effector function exerts the observed effects. The heterogeneity of the IL17producing $\mathrm{T}$ cell population might also be the reason for the controversial findings in terms of T1D promotion or protection. 
As already mentioned above (cf. section 'Gut Microbiota and their Effect on T1D') our recent study in MyD88-deficient NOD mice suggests that in addition to the adaptive immunity including Th1 and Th17 responses, innate immunity plays an important role in gut immune responses in health and disease.

Pattern recognition receptors (PRR) like TLRs and nucleotide oligomerization domain-like receptor (NLRs) are highly expressed on intestinal epithelial cells and recognize conserved microbial components [84]. PRR play a crucial role in the initiation of immune responses. NOD mice that are deficient in a specific TLR exhibit an altered composition of gut microbiome and an altered diabetes development depending on which specific TLR deficiency (Gülden et al, unpublished data). Further studies are needed to elucidate the role of innate immunity in shaping the gut microbiome and altering diabetes development.

\section{Potential Therapeutic Strategies}

As described in section 4 (Diet, Gut Microbiota and T1D) pre- and probiotics can be considered as potential therapeutic tools to improve gut integrity in T1D. The beneficial effect of probiotics on the host's physiology is, however, not limited to the improvement of gut integrity.

As all microbes probiotics can shape host responses by direct interaction with cell wall bound molecules or via secreted products. Heat-killed probiotics cannot exert influence on the host through secreted products but are still able to interact with cell wall bound molecules. As early as 1997 a study by Matsuzaki and coworkers demonstrated that the application of heat-killed Lactobacillus casei prevented the onset of T1D in NOD mice [85]. The underlying mechanism, however, remained unclear. This study prompted Calcinaro and colleagues to administer a mixture of different strains of viable lyophilized probiotic bacteria to NOD mice which resulted in the induction of IL-10 and prevention from T1D [86]. Thus, probiotics are considered as potential tools for novel T1D therapies. These findings, however, have not been seen in all studies. Our own unpublished work (Peng et al, unpublished) had shown that probiotic treatment only has protective effects when started soon after weaning and continued for several months. The effects were no longer seen if the treatment was interrupted.

The challenge of developing new therapeutic intervention strategies for the treatment of T1D is to find an approach that is efficient without causing serious side effects. Current approaches aim at curing T1D by antigen-specific therapies and systemic immunomodulation and immunosuppression [87-89]. However, many strategies induce intense side effects due to suppression of immune responses. Antigen-specific therapies are attractive since they target only beta cell-reactive $\mathrm{T}$ cells without affecting general immune responses. Yet the common oral administration method results in reduced efficacy due to degradation during the passage of the gastrointestinal tract.

Novel therapeutic strategies have been designed to overcome this issue by using engineered Lactococcus lactis bacteria as a safe and effective method to transport autoantigens to the immune system to induce tolerance [90-92]. Robert and coworkers demonstrated that a combination of genetically modified Lactococcus lactis that express GAD65 and IL-10 and 
short-term anti-CD3 treatment reversed diabetes in NOD mice [91]. This and other studies [90, 92] using engineered Lactococcus lactis suggest that genetically modified probiotics are safe and effective vectors for the treatment of T1D.

\section{Conclusion}

The research on gut microbiota and their interactions with the hosts has grown exponentially during the last 10 years or so, which has filled a huge gap in our knowledge. We have learned that many health problems including T1D can be influenced by the gut microbiome. GF mice provided a unique model system to conduct proof-of-concept studies. Although the overall composition rather than specific bacteria is likely to be more important for either pathogenic or protective effects on host health or disease, the knowledge of identified beneficial bacteria can be used to shape the gut microbiome in a positive way. It is clear that future research is required to test whether targeting the gut microbiome could be a basis for the establishment of potent new preventive or therapeutic T1D intervention strategies.

\section{Acknowledgments}

This work was supported by Deutsche Forschungsgemeinschaft fellowship GU 1122/3-1 (to EG), RC1 DK092882 and DK088181 (to LW), P30-DK045735 (to LW), EFSD/Novo Nordisk Programme (to FSW), MRC grant MR/ K021141/1 (to FSW).

\section{References}

1. Pociot F, McDermott MF. Genetics of type 1 diabetes mellitus. Genes and immunity. 2002; 3:235249. [PubMed: 12140742]

2. Harjutsalo V, Sjoberg L, Tuomilehto J. Time trends in the incidence of type 1 diabetes in Finnish children: a cohort study. Lancet. 2008; 371:1777-1782. [PubMed: 18502302]

3. Patterson CC, Dahlquist GG, Gyurus E, Green A, Soltesz G, Group ES. Incidence trends for childhood type 1 diabetes in Europe during 1989-2003 and predicted new cases 2005-20: a multicentre prospective registration study. Lancet. 2009; 373:2027-2033. [PubMed: 19481249]

4. Patterson CC, Gyurus E, Rosenbauer J, Cinek O, Neu A, Schober E, Parslow RC, Joner G, Svensson J, Castell C, Bingley PJ, Schoenle E, Jarosz-Chobot P, Urbonaite B, Rothe U, Krzisnik C, IonescuTirgoviste C, Weets I, Kocova M, Stipancic G, Samardzic M, de Beaufort CE, Green A, Dahlquist GG, Soltesz G. Trends in childhood type 1 diabetes incidence in Europe during 1989-2008: evidence of non-uniformity over time in rates of increase. Diabetologia. 2012; 55:2142-2147. [PubMed: 22638547]

5. Visser J, Rozing J, Sapone A, Lammers K, Fasano A. Tight junctions, intestinal permeability, and autoimmunity: celiac disease and type 1 diabetes paradigms. Annals of the New York Academy of Sciences. 2009; 1165:195-205. [PubMed: 19538307]

6. Khashan AS, Kenny LC, Lundholm C, Kearney PM, Gong T, Almqvist C. Mode of obstetrical delivery and type 1 diabetes: a sibling design study. Pediatrics. 2014; 134:e806-813. [PubMed: 25092933]

7. Cardwell CR, Stene LC, Joner G, Cinek O, Svensson J, Goldacre MJ, Parslow RC, Pozzilli P, Brigis G, Stoyanov D, Urbonaite B, Sipetic S, Schober E, Ionescu-Tirgoviste C, Devoti G, de Beaufort $\mathrm{CE}$, Buschard K, Patterson CC. Caesarean section is associated with an increased risk of childhoodonset type 1 diabetes mellitus: a meta-analysis of observational studies. Diabetologia. 2008; 51:726-735. [PubMed: 18292986]

8. Kimpimaki T, Erkkola M, Korhonen S, Kupila A, Virtanen SM, Ilonen J, Simell O, Knip M. Shortterm exclusive breastfeeding predisposes young children with increased genetic risk of Type I diabetes to progressive beta-cell autoimmunity. Diabetologia. 2001; 44:63-69. [PubMed: 11206413] 
9. Holmberg H, Wahlberg J, Vaarala O, Ludvigsson J, Group AS. Short duration of breast-feeding as a risk-factor for beta-cell autoantibodies in 5-year-old children from the general population. The British journal of nutrition. 2007; 97:111-116. [PubMed: 17217566]

10. Norris JM, Barriga K, Klingensmith G, Hoffman M, Eisenbarth GS, Erlich HA, Rewers M. Timing of initial cereal exposure in infancy and risk of islet autoimmunity. Jama. 2003; 290:1713-1720. [PubMed: 14519705]

11. Ziegler AG, Schmid S, Huber D, Hummel M, Bonifacio E. Early infant feeding and risk ofdeveloping type 1 diabetes-associated autoantibodies. Jama. 2003; 290:1721-1728. [PubMed: 14519706]

12. Brugman S, Klatter FA, Visser JT, Wildeboer-Veloo AC, Harmsen HJ, Rozing J, Bos NA. Antibiotic treatment partially protects against type 1 diabetes in the Bio-Breeding diabetes-prone rat. Is the gut flora involved in the development of type 1 diabetes? Diabetologia. 2006; 49:21052108. [PubMed: 16816951]

13. Hansen CH, Krych L, Nielsen DS, Vogensen FK, Hansen LH, Sorensen SJ, Buschard K, Hansen AK. Early life treatment with vancomycin propagates Akkermansia muciniphila and reduces diabetes incidence in the NOD mouse. Diabetologia. 2012; 55:2285-2294. [PubMed: 22572803]

14. C. Human Microbiome Project. Structure, function and diversity of the healthy human microbiome. Nature. 2012; 486:207-214. [PubMed: 22699609]

15. Bach JF. The effect of infections on susceptibility to autoimmune and allergic diseases. The New England journal of medicine. 2002; 347:911-920. [PubMed: 12239261]

16. Blaser MJ, Falkow S. What are the consequences of the disappearing human microbiota? Nature reviews Microbiology. 2009; 7:887-894.

17. Brown CT, Davis-Richardson AG, Giongo A, Gano KA, Crabb DB, Mukherjee N, Casella G, Drew JC, Ilonen J, Knip M, Hyoty H, Veijola R, Simell T, Simell O, Neu J, Wasserfall CH, Schatz D, Atkinson MA, Triplett EW. Gut microbiome metagenomics analysis suggests a functional model for the development of autoimmunity for type 1 diabetes. PloS one. 2011; 6:e25792. [PubMed: 22043294]

18. Giongo A, Gano KA, Crabb DB, Mukherjee N, Novelo LL, Casella G, Drew JC, Ilonen J, Knip M, Hyoty H, Veijola R, Simell T, Simell O, Neu J, Wasserfall CH, Schatz D, Atkinson MA, Triplett EW. Toward defining the autoimmune microbiome for type 1 diabetes. The ISME journal. 2011; 5:82-91. [PubMed: 20613793]

19. Dunne JL, Triplett EW, Gevers D, Xavier R, Insel R, Danska J, Atkinson MA. The intestinal microbiome in type 1 diabetes. Clinical and experimental immunology. 2014; 177:30-37. [PubMed: 24628412]

20. de Goffau MC, Fuentes S, van den Bogert B, Honkanen H, de Vos WM, Welling GW, Hyoty H, Harmsen HJ. Aberrant gut microbiota composition at the onset of type 1 diabetes in young children. Diabetologia. 2014; 57:1569-1577. [PubMed: 24930037]

21. de Goffau MC, Luopajarvi K, Knip M, Ilonen J, Ruohtula T, Harkonen T, Orivuori L, Hakala S, Welling GW, Harmsen HJ, Vaarala O. Fecal microbiota composition differs between children with beta-cell autoimmunity and those without. Diabetes. 2013; 62:1238-1244. [PubMed: 23274889]

22. Pozzilli P, Signore A, Williams AJ, Beales PE. NOD mouse colonies around the world-recent facts and figures. Immunology today. 1993; 14:193-196. [PubMed: 8517916]

23. King C, Sarvetnick N. The incidence of type-1 diabetes in NOD mice is modulated by restricted flora not germ-free conditions. PloS one. 2011; 6:e17049. [PubMed: 21364875]

24. Alam C, Bittoun E, Bhagwat D, Valkonen S, Saari A, Jaakkola U, Eerola E, Huovinen P, Hanninen A. Effects of a germ-free environment on gut immune regulation and diabetes progression in nonobese diabetic (NOD) mice. Diabetologia. 2011; 54:1398-1406. [PubMed: 21380595]

25. Akira S, Takeda K. Toll-like receptor signalling. Nature reviews Immunology. 2004; 4:499-511.

26. Wen L, Ley RE, Volchkov PY, Stranges PB, Avanesyan L, Stonebraker AC, Hu C, Wong FS, Szot GL, Bluestone JA, Gordon JI, Chervonsky AV. Innate immunity and intestinal microbiota in the development of Type 1 diabetes. Nature. 2008; 455:1109-1113. [PubMed: 18806780]

27. Valladares R, Sankar D, Li N, Williams E, Lai KK, Abdelgeliel AS, Gonzalez CF, Wasserfall CH, Larkin J, Schatz D, Atkinson MA, Triplett EW, Neu J, Lorca GL. Lactobacillus johnsonii N6.2 
mitigates the development of type 1 diabetes in BB-DP rats. PloS one. 2010; 5:e10507. [PubMed: 20463897]

28. Kriegel MA, Sefik E, Hill JA, Wu HJ, Benoist C, Mathis D. Naturally transmitted segmented filamentous bacteria segregate with diabetes protection in nonobese diabetic mice. Proceedings of the National Academy of Sciences of the United States of America. 2011; 108:11548-11553. [PubMed: 21709219]

29. Yurkovetskiy L, Burrows M, Khan AA, Graham L, Volchkov P, Becker L, Antonopoulos D, Umesaki Y, Chervonsky AV. Gender bias in autoimmunity is influenced by microbiota. Immunity. 2013; 39:400-412. [PubMed: 23973225]

30. Van Itallie CM, Anderson JM. Architecture of tight junctions and principles of molecular composition. Seminars in cell \& developmental biology. 2014

31. Vetrano S, Rescigno M, Cera MR, Correale C, Rumio C, Doni A, Fantini M, Sturm A, Borroni E, Repici A, Locati M, Malesci A, Dejana E, Danese S. Unique role of junctional adhesion moleculea in maintaining mucosal homeostasis in inflammatory bowel disease. Gastroenterology. 2008; 135:173-184. [PubMed: 18514073]

32. Zeissig S, Burgel N, Gunzel D, Richter J, Mankertz J, Wahnschaffe U, Kroesen AJ, Zeitz M, Fromm M, Schulzke JD. Changes in expression and distribution of claudin 2, 5 and 8 lead to discontinuous tight junctions and barrier dysfunction in active Crohn's disease. Gut. 2007; 56:6172. [PubMed: 16822808]

33. Vogelsang H, Schwarzenhofer M, Oberhuber G. Changes in gastrointestinal permeability in celiac disease. Digestive diseases. 1998; 16:333-336. [PubMed: 10207217]

34. Ghoshal UC, Shukla R, Ghoshal U, Gwee KA, Ng SC, Quigley EM. The gut microbiota and irritable bowel syndrome: friend or foe? International journal of inflammation. 2012; 2012:151085. [PubMed: 22577594]

35. Bosi E, Molteni L, Radaelli MG, Folini L, Fermo I, Bazzigaluppi E, Piemonti L, Pastore MR, Paroni R. Increased intestinal permeability precedes clinical onset of type 1 diabetes. Diabetologia. 2006; 49:2824-2827. [PubMed: 17028899]

36. Secondulfo M, Iafusco D, Carratu R, deMagistris L, Sapone A, Generoso M, Mezzogiomo A, Sasso FC, Carteni M, De Rosa R, Prisco F, Esposito V. Ultrastructural mucosal alterations and increased intestinal permeability in non-celiac, type I diabetic patients. Digestive and liver disease : official journal of the Italian Society of Gastroenterology and the Italian Association for the Study of the Liver. 2004; 36:35-45.

37. Neu J, Reverte CM, Mackey AD, Liboni K, Tuhacek-Tenace LM, Hatch M, Li N, Caicedo RA, Schatz DA, Atkinson M. Changes in intestinal morphology and permeability in the biobreeding rat before the onset of type 1 diabetes. Journal of pediatric gastroenterology and nutrition. 2005; 40:589-595. [PubMed: 15861021]

38. Meddings JB, Jarand J, Urbanski SJ, Hardin J, Gall DG. Increased gastrointestinal permeability is an early lesion in the spontaneously diabetic BB rat. The American journal of physiology. 1999; 276:G951-957. [PubMed: 10198339]

39. Patel RM, Myers LS, Kurundkar AR, Maheshwari A, Nusrat A, Lin PW. Probiotic bacteria induce maturation of intestinal claudin 3 expression and barrier function. The American journal of pathology. 2012; 180:626-635. [PubMed: 22155109]

40. Hadjiyanni I, Li KK, Drucker DJ. Glucagon-like peptide-2 reduces intestinal permeability but does not modify the onset of type 1 diabetes in the nonobese diabetic mouse. Endocrinology. 2009; 150:592-599. [PubMed: 18845625]

41. Lee AS, Gibson DL, Zhang Y, Sham HP, Vallance BA, Dutz JP. Gut barrier disruption by an enteric bacterial pathogen accelerates insulitis in NOD mice. Diabetologia. 2010; 53:741-748. [PubMed: 20012858]

42. Visser JT, Lammers K, Hoogendijk A, Boer MW, Brugman S, Beijer-Liefers S, Zandvoort A, Harmsen H, Welling G, Stellaard F, Bos NA, Fasano A, Rozing J. Restoration of impaired intestinal barrier function by the hydrolysed casein diet contributes to the prevention of type 1 diabetes in the diabetes-prone BioBreeding rat. Diabetologia. 2010; 53:2621-2628. [PubMed: 20853098] 
43. de Kort S, Keszthelyi D, Masclee AA. Leaky gut and diabetes mellitus: what is the link? Obesity reviews : an official journal of the International Association for the Study of Obesity. 2011; 12:449-458. [PubMed: 21382153]

44. Wang W, Uzzau S, Goldblum SE, Fasano A. Human zonulin, a potential modulator of intestinal tight junctions. Journal of cell science. 2000; 113 Pt 24:4435-4440. [PubMed: 11082037]

45. Groschwitz KR, Hogan SP. Intestinal barrier function: molecular regulation and disease pathogenesis. The Journal of allergy and clinical immunology. 2009; 124:3-20. quiz 21-22. [PubMed: 19560575]

46. Watts T, Berti I, Sapone A, Gerarduzzi T, Not T, Zielke R, Fasano A. Role of the intestinal tight junction modulator zonulin in the pathogenesis of type I diabetes in BB diabetic-prone rats. Proceedings of the National Academy of Sciences of the United States of America. 2005; 102:2916-2921. [PubMed: 15710870]

47. Kelly CP, Green PH, Murray JA, Dimarino A, Colatrella A, Leffler DA, Alexander T, Arsenescu R, Leon F, Jiang JG, Arterburn LA, Paterson BM, Fedorak RN, Larazotide G. Acetate Celiac Disease Study, Larazotide acetate in patients with coeliac disease undergoing a gluten challenge: a randomised placebo-controlled study. Alimentary pharmacology \& therapeutics. 2013; 37:252262. [PubMed: 23163616]

48. Vaarala O, Klemetti P, Savilahti E, Reijonen H, Ilonen J, Akerblom HK. Cellular immune response to cow's milk beta-lactoglobulin in patients with newly diagnosed IDDM. Diabetes. 1996; 45:178182. [PubMed: 8549862]

49. Hoorfar J, Buschard K, Dagnaes-Hansen F. Prophylactic nutritional modification of the incidence of diabetes in autoimmune non-obese diabetic (NOD) mice. The British journal of nutrition. 1993; 69:597-607. [PubMed: 8490012]

50. Funda DP, Kaas A, Bock T, Tlaskalova-Hogenova H, Buschard K. Gluten-free diet prevents diabetes in NOD mice. Diabetes/metabolism research and reviews. 1999; 15:323-327. [PubMed: 10585617]

51. Marietta EV, Gomez AM, Yeoman C, Tilahun AY, Clark CR, Luckey DH, Murray JA, White BA, Kudva YC, Rajagopalan G. Low incidence of spontaneous type 1 diabetes in non-obese diabetic mice raised on gluten-free diets is associated with changes in the intestinal microbiome. PloS one. 2013; 8:e78687. [PubMed: 24236037]

52. Patrick C, Wang GS, Lefebvre DE, Crookshank JA, Sonier B, Eberhard C, Mojibian M, Kennedy CR, Brooks SP, Kalmokoff ML, Maglio M, Troncone R, Poussier P, Scott FW. Promotion of autoimmune diabetes by cereal diet in the presence or absence of microbes associated with gut immune activation, regulatory imbalance, and altered cathelicidin antimicrobial Peptide. Diabetes. 2013; 62:2036-2047. [PubMed: 23349499]

53. Wolf KJ, Daft JG, Tanner SM, Hartmann R, Khafipour E, Lorenz RG. Consumption of acidic water alters the gut microbiome and decreases the risk of diabetes in NOD mice. The journal of histochemistry and cytochemistry : official journal of the Histochemistry Society. 2014; 62:237250. [PubMed: 24453191]

54. Hill C, Guarner F, Reid G, Gibson GR, Merenstein DJ, Pot B, Morelli L, Canani RB, Flint HJ, Salminen S, Calder PC, Sanders ME. Expert consensus document. The International Scientific Association for Probiotics and Prebiotics consensus statement on the scope and appropriate use of the term probiotic. Nature reviews Gastroenterology \& hepatology. 2014; 11:506-514. [PubMed: 24912386]

55. Karczewski J, Troost FJ, Konings I, Dekker J, Kleerebezem M, Brummer RJ, Wells JM. Regulation of human epithelial tight junction proteins by Lactobacillus plantarum in vivo and protective effects on the epithelial barrier. American journal of physiology Gastrointestinal and liver physiology. 2010; 298:G851-859. [PubMed: 20224007]

56. Pineiro M, Asp NG, Reid G, Macfarlane S, Morelli L, Brunser O, Tuohy K. FAO Technical meeting on prebiotics. Journal of clinical gastroenterology. 2008; 42 Suppl 3 Pt 2:S156-159. [PubMed: 18685504]

57. Cani PD, Possemiers S, Van de Wiele T, Guiot Y, Everard A, Rottier O, Geurts L, Naslain D, Neyrinck A, Lambert DM, Muccioli GG, Delzenne NM. Changes in gut microbiota control inflammation in obese mice through a mechanism involving GLP-2-driven improvement of gut permeability. Gut. 2009; 58:1091-1103. [PubMed: 19240062] 
58. Dominguez-Bello MG, Costello EK, Contreras M, Magris M, Hidalgo G, Fierer N, Knight R. Delivery mode shapes the acquisition and structure of the initial microbiota across multiple body habitats in newborns. Proceedings of the National Academy of Sciences of the United States of America. 2010; 107:11971-11975. [PubMed: 20566857]

59. Martin R, Heilig GH, Zoetendal EG, Smidt H, Rodriguez JM. Diversity of the Lactobacillus group in breast milk and vagina of healthy women and potential role in the colonization of the infant gut. Journal of applied microbiology. 2007; 103:2638-2644. [PubMed: 18045446]

60. Harmsen HJ, Wildeboer-Veloo AC, Raangs GC, Wagendorp AA, Klijn N, Bindels JG, Welling GW. Analysis of intestinal flora development in breast-fed and formula-fed infants by using molecular identification and detection methods. Journal of pediatric gastroenterology and nutrition. 2000; 30:61-67. [PubMed: 10630441]

61. Rubaltelli FF, Biadaioli R, Pecile P, Nicoletti P. Intestinal flora in breast- and bottle-fed infants. Journal of perinatal medicine. 1998; 26:186-191. [PubMed: 9773376]

62. Fallani M, Young D, Scott J, Norin E, Amarri S, Adam R, Aguilera M, Khanna S, Gil A, Edwards CA, Dore J. I.T. Other Members of the, Intestinal microbiota of 6-week-old infants across Europe: geographic influence beyond delivery mode, breast-feeding, and antibiotics. Journal of pediatric gastroenterology and nutrition. 2010; 51:77-84. [PubMed: 20479681]

63. Catassi C, Bonucci A, Coppa GV, Carlucci A, Giorgi PL. Intestinal permeability changes during the first month: effect of natural versus artificial feeding. Journal of pediatric gastroenterology and nutrition. 1995; 21:383-386. [PubMed: 8583288]

64. Van Immerseel F, Ducatelle R, De Vos M, Boon N, Van De Wiele T, Verbeke K, Rutgeerts P, Sas $\mathrm{B}$, Louis P, Flint HJ. Butyric acid-producing anaerobic bacteria as a novel probiotic treatment approach for inflammatory bowel disease. Journal of medical microbiology. 2010; 59:141-143. [PubMed: 19942690]

65. Peng L, Li ZR, Green RS, Holzman IR, Lin J. Butyrate enhances the intestinal barrier by facilitating tight junction assembly via activation of AMP-activated protein kinase in Caco- 2 cell monolayers. The Journal of nutrition. 2009; 139:1619-1625. [PubMed: 19625695]

66. Hansen CH, Andersen LS, Krych L, Metzdorff SB, Hasselby JP, Skov S, Nielsen DS, Buschard K, Hansen LH, Hansen AK. Mode of delivery shapes gut colonization pattern and modulates regulatory immunity in mice. Journal of immunology. 2014; 193:1213-1222.

67. Kirjavainen PV, Gibson GR. Healthy gut microflora and allergy: factors influencing development of the microbiota. Annals of medicine. 1999; 31:288-292. [PubMed: 10480760]

68. Peng J, Narasimhan S, Marchesi JR, Benson A, Wong FS, Wen L. Long term effect of gut microbiota transfer on diabetes development. Journal of autoimmunity. 2014

69. Ochoa-Reparaz J, Mielcarz DW, Ditrio LE, Burroughs AR, Foureau DM, Haque-Begum S, Kasper LH. Role of gut commensal microflora in the development of experimental autoimmune encephalomyelitis. Journal of immunology. 2009; 183:6041-6050.

70. Tormo-Badia N, Hakansson A, Vasudevan K, Molin G, Ahrne S, Cilio CM. Antibiotic treatment of pregnant non-obese diabetic (NOD) mice leads to altered gut microbiota and intestinal immunological changes in the offspring. Scandinavian journal of immunology. 2014

71. Cox LM, Blaser MJ. Antibiotics in early life and obesity. Nature reviews Endocrinology. 2015; 11:182-190.

72. Macpherson AJ, Harris NL. Interactions between commensal intestinal bacteria and the immune system. Nature reviews Immunology. 2004; 4:478-485.

73. Wesemann DR, Portuguese AJ, Meyers RM, Gallagher MP, Cluff-Jones K, Magee JM, Panchakshari RA, Rodig SJ, Kepler TB, Alt FW. Microbial colonization influences early Blineage development in the gut lamina propria. Nature. 2013; 501:112-115. [PubMed: 23965619]

74. Ostman S, Rask C, Wold AE, Hultkrantz S, Telemo E. Impaired regulatory T cell function in germ-free mice. European journal of immunology. 2006; 36:2336-2346. [PubMed: 16897813]

75. Round JL, Mazmanian SK. The gut microbiota shapes intestinal immune responses during health and disease. Nature reviews Immunology. 2009; 9:313-323.

76. Round JL, Mazmanian SK. Inducible Foxp3+ regulatory T-cell development by a commensal bacterium of the intestinal microbiota. Proceedings of the National Academy of Sciences of the United States of America. 2010; 107:12204-12209. [PubMed: 20566854] 
77. Furusawa Y, Obata Y, Fukuda S, Endo TA, Nakato G, Takahashi D, Nakanishi Y, Uetake C, Kato K, Kato T, Takahashi M, Fukuda NN, Murakami S, Miyauchi E, Hino S, Atarashi K, Onawa S, Fujimura Y, Lockett T, Clarke JM, Topping DL, Tomita M, Hori S, Ohara O, Morita T, Koseki H, Kikuchi J, Honda K, Hase K, Ohno H. Commensal microbe-derived butyrate induces the differentiation of colonic regulatory T cells. Nature. 2013; 504:446-450. [PubMed: 24226770]

78. Arpaia N, Campbell C, Fan X, Dikiy S, van der Veeken J, deRoos P, Liu H, Cross JR, Pfeffer K, Coffer PJ, Rudensky AY. Metabolites produced by commensal bacteria promote peripheral regulatory T-cell generation. Nature. 2013; 504:451-455. [PubMed: 24226773]

79. Emamaullee JA, Davis J, Merani S, Toso C, Elliott JF, Thiesen A, Shapiro AM. Inhibition of Th17 cells regulates autoimmune diabetes in NOD mice. Diabetes. 2009; 58:1302-1311. [PubMed: 19289457]

80. Honkanen J, Nieminen JK, Gao R, Luopajarvi K, Salo HM, Ilonen J, Knip M, Otonkoski T, Vaarala O. IL-17 immunity in human type 1 diabetes. Journal of immunology. 2010; 185:19591967.

81. Lau K, Benitez P, Ardissone A, Wilson TD, Collins EL, Lorca G, Li N, Sankar D, Wasserfall C, Neu J, Atkinson MA, Shatz D, Triplett EW, Larkin J 3rd. Inhibition of type 1 diabetes correlated to a Lactobacillus johnsonii N6.2-mediated Th17 bias. Journal of immunology. 2011; 186:35383546.

82. Ivanov II, Frutos Rde L, Manel N, Yoshinaga K, Rifkin DB, Sartor RB, Finlay BB, Littman DR. Specific microbiota direct the differentiation of IL-17-producing T-helper cells in the mucosa of the small intestine. Cell host \& microbe. 2008; 4:337-349. [PubMed: 18854238]

83. Ivanov II, Atarashi K, Manel N, Brodie EL, Shima T, Karaoz U, Wei D, Goldfarb KC, Santee CA, Lynch SV, Tanoue T, Imaoka A, Itoh K, Takeda K, Umesaki Y, Honda K, Littman DR. Induction of intestinal Th17 cells by segmented filamentous bacteria. Cell. 2009; 139:485-498. [PubMed: 19836068]

84. Kamada N, Seo SU, Chen GY, Nunez G. Role of the gut microbiota in immunity and inflammatory disease, Nature reviews. Immunology. 2013; 13:321-335. [PubMed: 23618829]

85. Matsuzaki T, Nagata Y, Kado S, Uchida K, Kato I, Hashimoto S, Yokokura T. Prevention of onset in an insulin-dependent diabetes mellitus model, NOD mice, by oral feeding of Lactobacillus casei. APMIS : acta pathologica, microbiologica, et immunologica Scandinavica. 1997; 105:643649.

86. Calcinaro F, Dionisi S, Marinaro M, Candeloro P, Bonato V, Marzotti S, Corneli RB, Ferretti E, Gulino A, Grasso F, De Simone C, Di Mario U, Falorni A, Boirivant M, Dotta F. Oral probiotic administration induces interleukin-10 production and prevents spontaneous autoimmune diabetes in the non-obese diabetic mouse. Diabetologia. 2005; 48:1565-1575. [PubMed: 15986236]

87. van Belle TL, Coppieters KT, von Herrath MG. Type 1 diabetes: etiology, immunology, and therapeutic strategies. Physiological reviews. 2011; 91:79-118. [PubMed: 21248163]

88. Herold KC, Gitelman S, Greenbaum C, Puck J, Hagopian W, Gottlieb P, Sayre P, Bianchine P, Wong E, Seyfert-Margolis V, Bourcier K, Bluestone JA. I.T.N.A.I.S.G. Immune Tolerance Network, Treatment of patients with new onset Type 1 diabetes with a single course of anti-CD3 mAb Teplizumab preserves insulin production for up to 5 years. Clinical immunology. 2009; 132:166-173. [PubMed: 19443276]

89. Ludvigsson J, Faresjo M, Hjorth M, Axelsson S, Cheramy M, Pihl M, Vaarala O, Forsander G, Ivarsson S, Johansson C, Lindh A, Nilsson NO, Aman J, Ortqvist E, Zerhouni P, Casas R. GAD treatment and insulin secretion in recent-onset type 1 diabetes. The New England journal of medicine. 2008; 359:1909-1920. [PubMed: 18843118]

90. Ma Y, Liu J, Hou J, Dong Y, Lu Y, Jin L, Cao R, Li T, Wu J. Oral administration of recombinant Lactococcus lactis expressing HSP65 and tandemly repeated P277 reduces the incidence of type I diabetes in non-obese diabetic mice. PloS one. 2014; 9:e105701. [PubMed: 25157497]

91. Robert S, Gysemans C, Takiishi T, Korf H, Spagnuolo I, Sebastiani G, Van Huynegem K, Steidler L, Caluwaerts S, Demetter P, Wasserfall CH, Atkinson MA, Dotta F, Rottiers P, Van Belle TL, Mathieu C. Oral delivery of glutamic acid decarboxylase (GAD)-65 and IL10 by Lactococcus lactis reverses diabetes in recent-onset NOD mice. Diabetes. 2014; 63:2876-2887. [PubMed: 24677716] 
92. Takiishi T, Korf H, Van Belle TL, Robert S, Grieco FA, Caluwaerts S, Galleri L, Spagnuolo I, Steidler L, Van Huynegem K, Demetter P, Wasserfall C, Atkinson MA, Dotta F, Rottiers P, Gysemans C, Mathieu C. Reversal of autoimmune diabetes by restoration of antigen-specific tolerance using genetically modified Lactococcus lactis in mice. The Journal of clinical investigation. 2012; 122:1717-1725. [PubMed: 22484814]

93. Talja I, Kubo AL, Veijola R, Knip M, Simell O, Ilonen J, Vaha-Makila M, Sepp E, Mikelsaar M, Utt M, Uibo R. Antibodies to Lactobacilli and Bifidobacteria in young children with different propensity to develop islet autoimmunity. Journal of immunology research. 2014; 2014:325938. [PubMed: 24741589]

94. Soyucen E, Gulcan A, Aktuglu-Zeybek AC, Onal H, Kiykim E, Aydin A. Differences in the gut microbiota of healthy children and those with type 1 diabetes. Pediatrics international : official journal of the Japan Pediatric Society. 2014; 56:336-343. [PubMed: 24475780]

95. Murri M, Leiva I, Gomez-Zumaquero JM, Tinahones FJ, Cardona F, Soriguer F, Queipo-Ortuno MI. Gut microbiota in children with type 1 diabetes differs from that in healthy children: a casecontrol study. BMC medicine. 2013; 11:46. [PubMed: 23433344]

96. Mejia-Leon ME, Petrosino JF, Ajami NJ, Dominguez-Bello MG, de la Barca AM. Fecal microbiota imbalance in Mexican children with type 1 diabetes. Scientific reports. 2014; 4:3814. [PubMed: 24448554]

97. Hara N, Alkanani AK, Ir D, Robertson CE, Wagner BD, Frank DN, Zipris D. Prevention of virusinduced type 1 diabetes with antibiotic therapy. Journal of immunology. 2012; 189:3805-3814.

98. Roesch LF, Lorca GL, Casella G, Giongo A, Naranjo A, Pionzio AM, Li N, Mai V, Wasserfall $\mathrm{CH}$, Schatz D, Atkinson MA, Neu J, Triplett EW. Culture-independent identification of gut bacteria correlated with the onset of diabetes in a rat model. The ISME journal. 2009; 3:536-548. [PubMed: 19225551]

99. Sapone A, de Magistris L, Pietzak M, Clemente MG, Tripathi A, Cucca F, Lampis R, Kryszak D, Carteni M, Generoso M, Iafusco D, Prisco F, Laghi F, Riegler G, Carratu R, Counts D, Fasano A. Zonulin upregulation is associated with increased gut permeability in subjects with type 1 diabetes and their relatives. Diabetes. 2006; 55:1443-1449. [PubMed: 16644703]

100. Mooradian AD, Morley JE, Levine AS, Prigge WF, Gebhard RL. Abnormal intestinal permeability to sugars in diabetes mellitus. Diabetologia. 1986; 29:221-224. [PubMed: 3519337]

101. Damci T, Nuhoglu I, Devranoglu G, Osar Z, Demir M, Ilkova H. Increased intestinal permeability as a cause of fluctuating postprandial blood glucose levels in Type 1 diabetic patients. European journal of clinical investigation. 2003; 33:397-401. [PubMed: 12713453]

102. Kuitunen M, Saukkonen T, Ilonen J, Akerblom HK, Savilahti E. Intestinal permeability to mannitol and lactulose in children with type 1 diabetes with the HLA-DQB1*02 allele. Autoimmunity. 2002; 35:365-368. [PubMed: 12515291]

103. Carratu R, Secondulfo M, de Magistris L, Iafusco D, Urio A, Carbone MG, Pontoni G, Carteni M, Prisco F. Altered intestinal permeability to mannitol in diabetes mellitus type I. Journal of pediatric gastroenterology and nutrition. 1999; 28:264-269. [PubMed: 10067726]

104. Graham S, Courtois P, Malaisse WJ, Rozing J, Scott FW, Mowat AM. Enteropathy precedes type 1 diabetes in the BB rat. Gut. 2004; 53:1437-1444. [PubMed: 15361491] 


\section{Highlights}

- Gut microbiota have been shown to play an important role in promoting or protecting from T1D development

- Gut microbiota modulate the host immune system

- Change of gut permeability may precede the clinical onset of T1D

- The route of birth delivery and early life environment including feeding method shape the composition of the gut microbiome 




Fig. 1. Genetic and non-genetic factors determine the risk of developing diabetes in genetically predisposed individuals

T1D is a T cell-mediated autoimmune disease which occurs in genetically predisposed individuals when triggered by so far mostly unknown factors. In addition to genetics, environmental factors like diet, antibiotic usage, 'hygiene' and delivery mode may determine disease risk. Most of these environmental factors influence the gut microbiome composition, which is in close interaction with the immune system, and plays a role in shaping it. The gut microbiome composition also affects gut permeability. Increased gut permeability, thus a facilitated passage of luminal, potentially diabetogenic antigens, is suggested to play a role in initiating islet-directed autoimmunity. 
Table 1

Gut microbiota related studies

\begin{tabular}{|c|c|c|c|}
\hline Bacteria & Animal model/study group & Outcome & Ref. \\
\hline B. adolescentis DSM 20083 & children at risk to develop T1D & $\begin{array}{l}\text { probably involved in predisposing children to } \\
\beta \text { cell autoimmunity }\end{array}$ & [93] \\
\hline Bacteroidetes & seroconverted subjects & positively associated with islet autoimmunity & [19] \\
\hline Bacteroides, Eubacterium, Ruminococcus & BB-DP rats & more abundant & [98] \\
\hline Clostridium hylemonae & BB-DR rats & increased abundance & [98] \\
\hline Firmicutes, Bacteroidetes & NOD mice & $\begin{array}{l}\text { decrease in Firmicutes and an increase in } \\
\text { Bacteroidetes }\end{array}$ & [53] \\
\hline Bifidobacteria, Clostridium & LEW1. WR1 rat & $\begin{array}{l}\text { virus-induced T1D correlates with increased } \\
\text { Bifidobacteria and Clostridia }\end{array}$ & [97] \\
\hline Bacteroides ovatus, Bacteroides fragilis & T1D children & $\begin{array}{l}\text { increase in Bacteroides ovatus and decrease } \\
\text { in Bacteroides fragilis }\end{array}$ & [20] \\
\hline Firmicutes, Bacteroidetes & T1D children & $\begin{array}{l}\text { decreased abundances of Firmicutes; } \\
\text { increase abundance of Bacteroidetes }\end{array}$ & {$[17,18]$} \\
\hline Prevotella and Akkermansia & T1D children & $\begin{array}{l}\text { decreased abundance of Prevotella and } \\
\text { Akkermansia in T1D children }\end{array}$ & [17] \\
\hline Prevotella & T1D children & Prevotella genus was reduced in patients & {$[18,95,96]$} \\
\hline Bifidobacterium, Lactobacillus & T1D children & $\begin{array}{l}\text { decreased numbers of Bifidobacterium and } \\
\text { Lactobacillus }\end{array}$ & [95] \\
\hline Clostridium, Bacteroides, Veillonella & T1D children & $\begin{array}{l}\text { increased amount of Clostridium, } \\
\text { Bacteroides and Veillonella }\end{array}$ & [95] \\
\hline Lactate and butyrate producers & seropositive subjects & $\begin{array}{l}\text { lower levels of bacteria involved in the } \\
\text { production of lactate and butyrate }\end{array}$ & [21] \\
\hline Bacteroides, Prevotella & Mexican children with T1D & $\begin{array}{l}\text { high levels of the genus Bacteroides; control } \\
\text { group exhibit high levels of Prevotella }\end{array}$ & [96] \\
\hline Bifidobacteria & T1D children & $\begin{array}{l}\text { reduced Bifidobacteria, increased } \\
\text { Enterobacteriacea in T1D }\end{array}$ & [94] \\
\hline Firmicutes & seroconverted subjects & $\begin{array}{l}\text { negatively associated with islet } \\
\text { autoimmunity }\end{array}$ & [19] \\
\hline Faecalibacterium prausnitzii & $\begin{array}{l}\text { Children with diabetes-related } \\
\text { autoantibodies }\end{array}$ & $\begin{array}{l}\text { reduced abundance in children with two or } \\
\text { more diabetes-related autoantibodies }\end{array}$ & [21] \\
\hline Bifidobacteria & $\begin{array}{l}\text { Children with diabetes-related } \\
\text { autoantibodies }\end{array}$ & $\begin{array}{l}\text { negatively associated with } \beta \text { cell } \\
\text { autoimmunity }\end{array}$ & [21] \\
\hline Bifidobacteria & T1D children & $\begin{array}{l}\text { negatively associated with } \beta \text { cell } \\
\text { autoimmunity }\end{array}$ & {$[94,95]$} \\
\hline Lactic acid bacteria & NOD mice; BB-DP rats & delay or prevent diabetes & {$[85,86]$} \\
\hline Lactobacillus, Bifidobacterium & BB-DR rats & negatively correlated with T1D onset & [98] \\
\hline Lactobacillus johnsonii N6.2 & BB-DP rats & delayed diabetes onset & [27] \\
\hline SFB & NOD mice & diabetes protection & [28] \\
\hline Lactobacillus species & $\mathrm{BB}$ rats & negatively correlated with T1D development & [98] \\
\hline A. muciniphila & NOD mice & protective role in T1D development & [13] \\
\hline
\end{tabular}



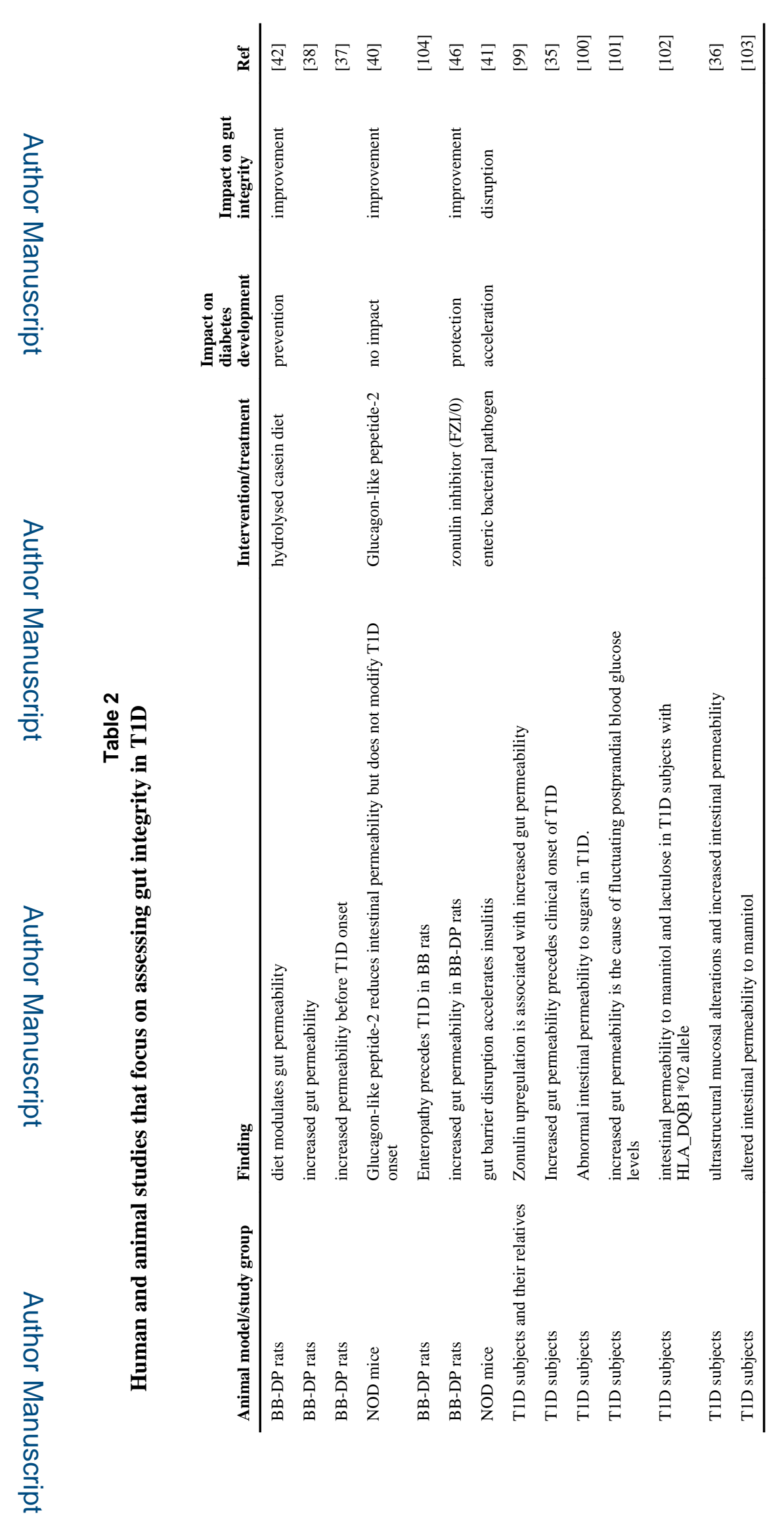



ำ

$$
\text { }
$$

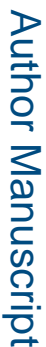

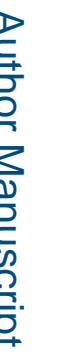

Clin Immunol. Author manuscript; available in PMC 2016 August 01. 